МАТЕРІАЛОЗНАВСТВО ТА МАШИНОБУДУВАННЯ

DOI: $10.20535 / 1810-0546.2018 .2 .129140$

UDC 532, 533

\author{
I. Nesteruk ${ }^{1,2 *}$, M. Brühl ${ }^{3}$, T. Möller ${ }^{3}$ \\ ${ }^{1}$ Institute of Hydromechanics, NAS of Ukraine, Kyiv, Ukraine \\ ${ }^{2}$ Igor Sikorsky Kyiv Polytechnic Institute, Kyiv, Ukraine \\ ${ }^{3}$ Technische Universität Braunschweig, Braunschweig, Germany
}

\title{
TESTING A SPECIAL SHAPED BODY OF REVOLUTION SIMILAR TO DOLPHINS TRUNK
}

Background. The high swimming velocities of some aquatic animals such as dolphins continue to attract great interest of researchers. The friction drag of the dolphin, estimated with the use of turbulent friction coefficient of the flat plate, was so high to declare that the dolphin should not be able to swim as fast as it does with the muscle power it possesses. Some previous tests of the rigid bodies, similar to the animal shapes, and gliding dolphins revealed the attached flow patterns. Nevertheless, the researchers connected with industrial applications believe that separation is inevitable on every smooth shape, provided no active boundary-layer control methods (e.g., suction) are applied.

Objective. The aim of the paper is to test a special shaped rigid body of revolution in the wind tunnel in order to show that the boundary-layer separation can be removed without any active flow control methods.

Methods. Wind tunnel tests were carried out at velocities 15,35 , and $55 \mathrm{~m} / \mathrm{s}$. Static pressure measurements and the oil-flow visualization were used. For this study, we take the UA-2 special shaped model of $200 \mathrm{~mm}$ length and $56.78 \mathrm{~mm}$ of the maximum diameter. The closed version of the UA-2c model is similar to the dolphin body. The tests were carried out in the subsonic wind tunnel MUB of the Institut für Strömungsmechanik (ISM) at Technische Universität Braunschweig, Germany. The wind tunnel MUB of ISM is an actively cooled Goettingen type tunnel with a square section of $1.3 \mathrm{~m}$ and the turbulence level of about $0.2 \%$. The technique of oil-flow visualization was used to deliver information of the surface near flow. The color used is a mixture of thin mineral oil and petrol, in an optimized ratio. The very fine titan-dioxide particles and UV-light reactive polymer particles in the color deliver a high contrast picture of the flow directions with a high spatial resolution.

Results. The distribution of the static pressure and the oil-flow visualization are presented at three angles of attack. The flow pattern at zero angle of attack is probably attached and laminar.

Conclusions. Pressure measurements and the flow visualization on the special shaped body of revolution showed that it is probably possible to avoid separation in rather large range of the Reynolds numbers. Further experiments are necessary with the use of a visualization of the flow volume and hot-wire velocity probes to clarify the behavior of the boundary layer, its separation and laminar-to-turbulent transition characteristics.

Keywords: wind tunnel tests; drag reduction; boundary layer separation; flow visualization; aquatic animals.

\section{Introduction}

The high swimming velocities of some aquatic animals such as dolphins continue to attract great interest of researchers. The values of the Reynolds number $\operatorname{Re}_{L}=U L / v$, where $U$ is the movement velocity, $L$ is the the body length, $v$ is the kinematic viscosity coefficient, exceed ten millions in the case of dolphin. The friction drag of the dolphin, estimated with the use of turbulent friction coefficient of the flat plate, [1], was so high to declare that the dolphin should not be able to swim as fast as it does with the muscle power it possesses. Gray proposed in [1] to solve the paradox that the dolphin must reduce drag by maintaining a laminar flow in the boundary layer on its body, delaying the transition to turbulence by movements of its tail [1].
Testing of the rigid bodies, similar to the animal shapes at close to real values of the Reynolds number (approximately six million) [2], and gliding dolphins (during the inertial movement without a maneuvering and a shape change) [3], was carried out in order to explain the fact of he low drag by a very good shape only. From the point of view of these researches, the body shapes of good swimmers ensure the attached flow patterns. It is unclear, which methods were used in [2] to prove the absence of the boundary layer separation on the rigid animal like models. In [3] the bioluminescence was used to visualize the flow around the real gliding dolphins in natural conditions.

The Dolphin body was manufactured and tested by North American Aviation in 1967-1968 [4]. The profile NACA-66 was chosen for the shape of this body of revolution; its parameters were as follows: diameter $D=0.48 \mathrm{~m} ; L / D=3.33$; volume

\footnotetext{
*corresponding author: inesteruk@yahoo.com
} 
$V=0.159 \mathrm{~m}^{3}$. Unfortunately, neither flow visualization, nor pressure distribution measurements have been performed. Tests revealed rather small values of drag $X$ (the minimal value of the volumetric drag coefficient $C_{V}=2 X /\left(\rho U^{2} V^{2 / 3}\right) \approx 0.008$ at the volumetric Reynolds number $R_{V}=U V^{1 / 3} / \mathrm{v}=$ $=0.85 \cdot 10^{7} ; \rho$ is the water density. To compare this drag with an ideal case of a slender laminar unseparated body of revolution, formula

$$
C_{V} \approx \frac{4.7}{\sqrt{\operatorname{Re}_{V}}}
$$

can be used [5, 6]. Eq. (1) yields $C_{V}=0.0016$ for Dolphin body. The more slender body of Hansen and Hoyt [7] $(L / D=4.5 ; L=3.18 \mathrm{~m} ; D=$ $=0.71 \mathrm{~m})$ has the minimum experimental drag coefficient $C_{V}=0.007$ at $R_{V}=2.2 \cdot 10^{6}$ that is closer to the theoretical value $C_{V}=0.0032$, which can be calculated from (1).

The theoretical drag on different bodies of revolution calculated in Parsons et al., [8], Dodbele et al., [9], Zedan et al. [10], and Lutz \& Wagner [11] are rather different and significantly exceed the estimation (1). For example, in [10] the theoretical value $C_{V}=0.012$ at $R_{V}=1.5 \cdot 10^{7}$ was obtained, whereas the shape calculated by Parsons et al. [8] has 2.4 times less drag and Eq. (1) yields a ten times smaller value.

In the case of the attached flow pattern, slender bodies of revolution can delay laminarturbulent transitions on their surfaces and reduce the skin-friction drag. The corresponding critical values of the Reynolds number are estimated in [6, 12]. That is why the unseparated rigid bodies attract great interest of researchers. In this paper we present the results of wind tunnel experiments with such special shaped body of revolution.

\section{Problem Formulation}

A special shaped rigid body of revolution was tested in the wind tunnel in order to show that the boundary-layer separation can be removed without any active flow control methods.

\section{Materials and Methods}

Special shaped bodies of revolution with negative pressure gradients. Body UA-2. For the last 20 years the possibility of achieving a laminar at- tached flow on a rigid body has been investigated in the Institute of Hydromechanics (IHM) of National Academy of Sciences, Kyiv, Ukraine. The survey of these theoretical and experimental studies is presented in [13]. In particular, shape UA-2c shown in Fig. 1 was calculated by a special distribution of the sources and sinks on the axis of symmetry. The stream function of the axisymmetric potential flow of the inviscid incompressible fluid was represented as follows [13, 14]:

$$
\begin{gathered}
\Psi(x, r)=0.5 r^{2}+\beta_{1} u\left(x_{*}\right)-0.75 E\left\{a \left[F_{1}\left(x_{*}\right)\right.\right. \\
\left.-F_{1}(0)\right]+a_{1}\left[F_{1}(1)-F_{1}\left(x_{*}\right)\right]+2(a x+2 c)\left[F_{2}\left(x_{*}\right)\right. \\
\left.\left.-F_{2}(0)\right]+2 a_{1}(x-1)\left[F_{2}(1)-F_{2}\left(x_{*}\right)\right]\right\} \\
\beta_{1}=0.75 E\left[a x_{*}^{2}+4 c x_{*}-a_{1}\left(x_{*}-1\right)^{2}\right] \\
u(s)=\sqrt{r^{2}+(s-x)^{2}} \\
F_{1}(s)=2 u^{3}(s) / 3 \\
F_{2}(s)=0.5(s-x) u(s)+0.5 r^{2} \ln [s-x+u(s)]
\end{gathered}
$$

where $x, r$ are cylindrical coordinates. The corresponding axisymmetric body radius $R(x)$, flow components $v_{x}, v_{r}$ and pressure coefficient on the surface were calculated with the use of following equations:

$$
\begin{gathered}
\Psi(x, R(x))=0, v_{x}=\frac{1}{r} \frac{\partial \Psi}{\partial r}, v_{r}=-\frac{1}{r} \frac{\partial \Psi}{\partial x}, \\
C_{p}(x)=1-v_{x}^{2}(x, R(x))-v_{r}^{2}(x, R(x)) .
\end{gathered}
$$
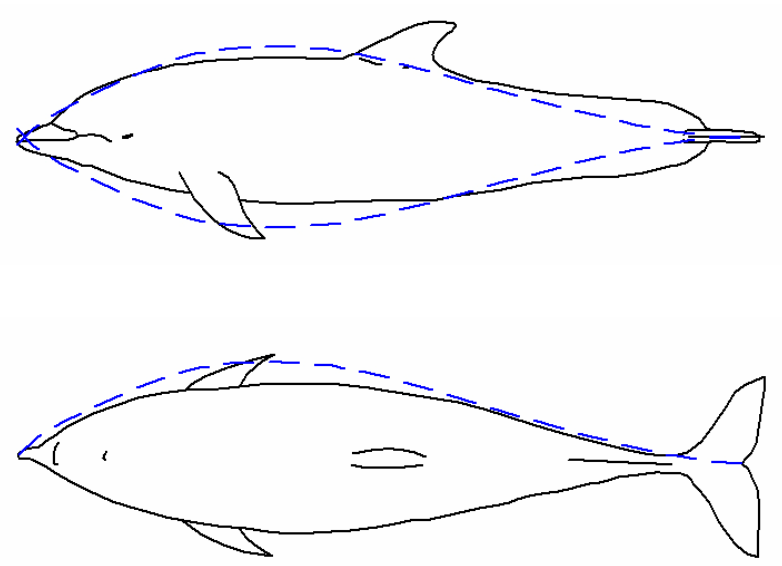

Fig. 1. Comparison of the shape UA-2c with the body of a bottlenose dolphin [6] 
Varying the values of constant parameters $x_{*}, a, a_{1}, c$ different closed $(R(L)=0)$ and unclosed $(R(L)>0)$ shapes can be obtained.

The closed body shape UA-2c has $L / D=3.6$, a negative-pressure-gradient forebody ending at the minimum pressure point $x \approx 0.33$, a long positivepressure-gradient region (approximately $45 \%$ of the total body length) and a negative pressure gradient near its tail [14]. The differences between this shape and the Dolphin body are shown in Fig. 2.

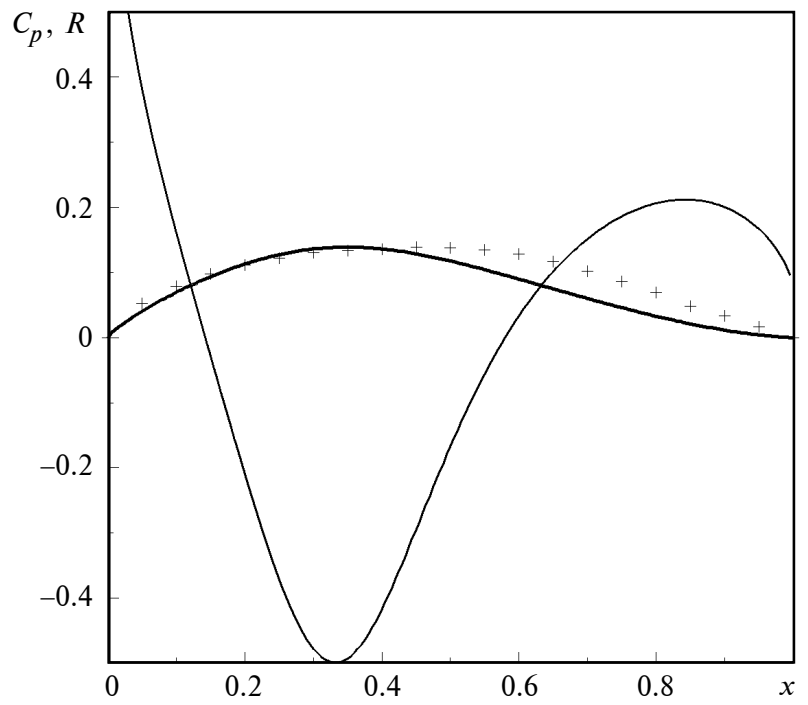

Fig. 2. Comparison of the special shaped body of revolution UA-2c with the "Dolphin-1" body based on profile NACA-66 [14]: — - $R(x)$, body UA-2c; -$C_{p}(x)$, body UA-2c; $+-R(x)$, "Dolphin-1" (NACA 66)

To fix the model on the wind tunnel, a support tube is necessary. Its presence was also simulated in [14] by the solution (2), (3), since the parameters $x_{*}, a, a_{1}, c$ allow changing the balance of the sinks and the sources. A result of the calculations - unclosed shape UA-2 - is shown in Fig. 3. Downstream to the point $x / L=1$ the body radius diminishes very slowly and $C_{p}$ is close to zero.

No visible separation and turbulence zones (e.g., the reversed flows) were revealed on body UA-2 in IHM tests, at all available flow velocities $\operatorname{Re}_{L} \leq 3 \times 10^{5}$ [13, 14]. In comparison, separation occurred on Goldschmied's body ( $D=0.508 \mathrm{~m}$; $L / D=2.9$; with a long negative pressure gradient forebody (appox. $76 \%$ of the total hull length), a short pressure increase zone (its length $d \approx 10 \%$ ) and a negative pressure gradient region near the tail) and was removed only with the use of boundary-layer suction, see [15].

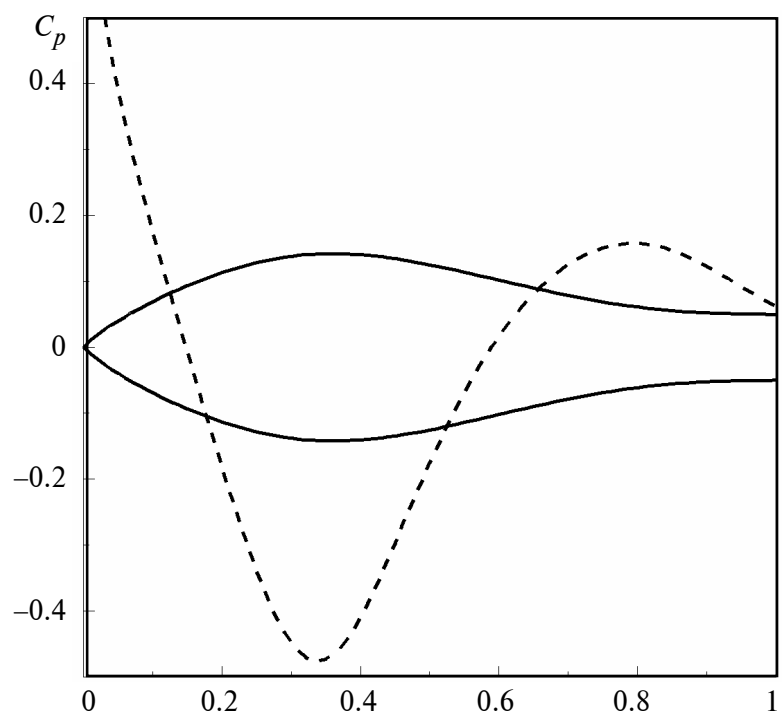

Fig. 3. Unclosed body of revolution UA-2. Shape (solid line) and theoretical pressure distribution (dashed line) [14]

It must be noted that only suction or blowing can be used to remove separation. Other active flow control methods usually use surface cooling/heating (e.g., [16]), different shape transformations (e.g., [17]) and even electromagnetic forces (e.g., [18]). Proper use of these methods can reduce or even remove the separation, but all of them need additional energy to be supplied. Usually, the authors make no estimations of this wasted energy.

In comparison, the passive flow control methods use only the rigid-body shape opportunities. It means that no external energy has to be added to perform the control. E.g., the passive methods can use a surface roughness to diminish the drag [19]). Here we concentrate on a smooth rigid body of revolution in order to remove separation.

In the IHM experiments a very significant discrepancy between the experimental und theoretical pressure distributions was revealed (see, [13, 14] and Fig. 5). The FLUENT code was used to simulate numerically the viscous flow over body UA-2, but the calculated pressure distribution was never close to the experimental one. In order to explain the differences in the theoretical and experimental pressure distributions, the inverse problems were solved in [20]. The experimental pressure data was used to calculate the corresponding body shape. The results show that the corresponding body of revolution must be much slenderer than the experimental model UA-2 (see [20]).

These facts urged us to analyze the pressure measurements in IHM tests and repeat the expe- 
riments in the Institut for Strцmungsmechanik (ISM) at Technische Universitдt Braunschweig, Germany. The subsonic wind tunnel MUB of ISM allows increasing the flow cross-section and Reynolds numbers, using different angles of attack and oil-flow visualization. The obtained results and discussions are presented in this paper.

The model, wind tunnels and peculiarities of the oil-flow visualization. For this study, we take the model UA-2 of $200 \mathrm{~mm}$ length and $56.78 \mathrm{~mm}$ of the maximum diameter. The shape was calculated in [14] with the use of eq. (2), (3) and is shown in Fig. 3. The closed version of the model - UA-2c is similar to the dolphin body (see Fig. 1). For the IHM experiments, downstream to the point $x / L=1$ the calculated shape was replaced by the cylindrical support tube of the $300 \mathrm{~mm}$ length and $19.98 \mathrm{~mm}$ external diameter. For the ISM tests we use of the same model of $200 \mathrm{~mm}$ length. The support is cylindrical $(205 \mathrm{~mm}$ length and $20 \mathrm{~mm}$ diameter), conical (82.2 mm length) and cylindrical $(50 \mathrm{~mm}$ diameter), see Fig. 4. The model was equipped with static pressure orifices.

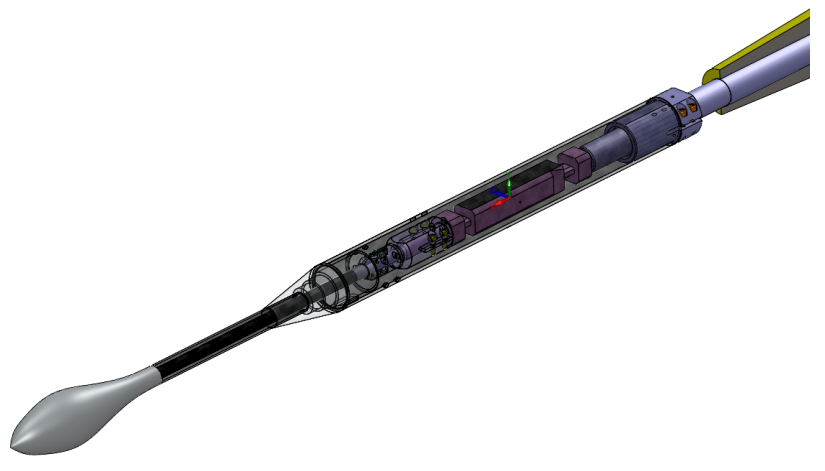

Fig. 4. Sketch of the model UA-2 and the support sting in MUB ISM

The first series of experiments was carried out in the low turbulence wind tunnel of Kyiv Institute of Hydromechanics, with test section cross section $200 \mathrm{~mm} \times 500 \mathrm{~mm}$ and maximum velocity $20 \mathrm{~m} / \mathrm{s}$, [13, 14]. The tests were performed for three ranges of the velocity $U_{\infty}: 5.7,10$, and $15 \mathrm{~m} / \mathrm{s}$ at zero angle of attack. A wire probe with a fine thread was used to visualize the flow. The pressure difference was measured to the accuracy $0.01 \mathrm{~mm}$ of a water column and the velocity to $0.1 \mathrm{~m} / \mathrm{s}$. To estimate the influence of wind tunnel walls and the vertical model support, the static pressure was measured by rotating the model. The discrepancy in values of $C_{p}$ for the various orifice positions did not exceed $15 \%$.
The second series of tests was carried out in the subsonic wind tunnel MUB of the Institut für Strömungsmechanik (ISM) at Technische Universität Braunschweig, Germany. The wind tunnel MUB of ISM is an actively cooled Goettingen type tunnel with a square section of $1.3 \mathrm{~m}$ and a $300 \mathrm{KW}$ drive for velocities up to $60 \mathrm{~m} / \mathrm{s}$. With flow straightening honey combs and several screens before the nozzle, which has a contraction ratio of 4.9, a characteristic turbulence level of about $0.2 \%$ is achieved. The experiments provided data for three different Reynolds numbers: $1.9 \times 10^{5}, 4.5 \times 10^{5}$ and $6.9 \times 10^{5}$ at velocities of $15 ; 35$ and $55 \mathrm{~m} / \mathrm{s}$ respectively.

The technique of oil-flow visualization was used to deliver information of the surface near flow. The color used is a mixture of thin mineral oil and petrol, in a ratio optimized for the involved forces. The very fine titan-dioxide particles and UV-light reactive polymer particles in the color deliver a high contrast picture of the flow directions with a high spatial resolution.

\section{Results and Discussion}

Tests at zero angle of attack. At zero angle of attack, the results of the pressure measurements in IHM and ISM are shown in Fig. 5 by blue and black markers respectively. At $0.2 \leq x / L \leq 0.45$ the large (in the case of IHM) and the significant (in the case of IHM) discrepancies between the experimental and theoretical data occur. In the same region on the body surface there is a big difference in the IHM and the ISM experimental data even in the same performance velocity range $15 \mathrm{~m} / \mathrm{s}$.

In order to explain these facts, a special investigation of the wall static pressure distribution along the IHM wind tunnel has been carried out. All of the static pressure orifices were located on the upper surface of the wind tunnel (with the $500 \mathrm{~mm}$ bright) along the longitudinal axes. To make the influence of the test body small, the distance of this line from the axis of symmetry was of $110 \mathrm{~mm}$. The first point was located at distance of $73 \mathrm{~mm}$ from the end of the confusor, the second one was located in the cross-section of the model nose ( $878 \mathrm{~mm}$ from the first orifice) the third and fourth orifices were located in the sections corresponding to the middle and the tail of the model $(978 \mathrm{~mm}$ and $1078 \mathrm{~mm}$ from the first orifice respectively). The experimental values of $C_{p i}=$ $=2\left(p_{i}-p_{1}\right) / \rho U_{\infty}^{2}$, where $p_{i}$ is the pressure in the 
point with the number $i$, for different velocities $U_{\infty}$ are presented in Table 1 .

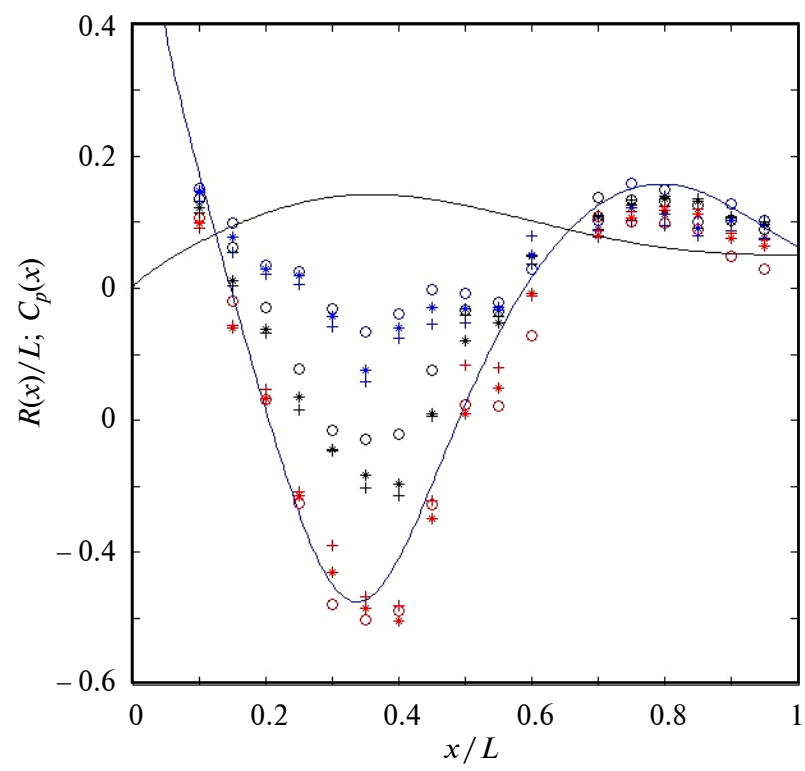

Fig. 5. Body UA-2. Shape, theoretical and experimental pressure distributions. Blue markers correspond to the experiments in IHM $\left(\operatorname{Re}_{L}=0.9 \times 10^{5} ; 1.5 \times 10^{5} ; 2.4 \times 10^{5}-\right.$ "circles"; "stars", and "crosses" respectively) [13, 14]. Black markers show the pressure measurements in MUB of ISM $\left(\operatorname{Re}_{L}=1.9 \times 10^{5} ; 4.5 \times 10^{5} ; 6.9 \times 10^{5}-\right.$ "circles", "stars", and "crosses" respectively). Red markers show the corrected pressure data in MUB of ISM $\left(\operatorname{Re}_{L}=1.9 \times 10^{5} ; 4.5 \times 10^{5} ; 6.9 \times 10^{5}\right.$ - "circles", "stars", and "crosses" respectively)

Table 1. Measured and theoretical pressure distributions on the IHM wind tunnel wall along the longitudinal axes with the presence of the model

\begin{tabular}{|l|c|c|c|}
\hline \multicolumn{1}{|c|}{ Characteristics } & $C_{p 2}$ & $C_{p 3}$ & $C_{p 4}$ \\
\hline$U_{\infty}=5.7 \mathrm{~m} / \mathrm{s}$ & -0.163 & -0.218 & -0.238 \\
\hline$U_{\infty}=10 \mathrm{~m} / \mathrm{s}$ & -0.190 & -0.236 & -0.247 \\
\hline$U_{\infty}=15 \mathrm{~m} / \mathrm{s}$ & -0.193 & -0.240 & -0.247 \\
\hline $\begin{array}{l}\text { Theoretical values of } \\
C_{p}, \text { eqs. (2), (3), at } \\
r / L=\sqrt{0.5^{2}+0.55^{2}}\end{array}$ & -0.00024 & -0.0098 & -0.0033 \\
\hline
\end{tabular}

It can be seen that a large pressure drop occurs along the IHM wind tunnel. To compensate this drop the wall pressure at the third point (located in the cross section of the model middle) was used to measure $C_{p}$ values shown in Fig. 5 and in $[13,14]$. On the other hand, the longitudinal pressure gradient on the wind tunnel wall is very high and can be a reason of discrepancies between the measured and theoretical pressure distributions. To illustrate this fact the theoretical values of $C_{p}$ are shown in Table 1. Solutions (2), (3) were used with the corresponding values of the radius $r / L=\sqrt{0.5^{2}+0.55^{2}}$ and $x / L=0 ; 0.5 ; 1$ for the points 2,3 , and 4 respectively.

The large pressure gradient along the IHM wind tunnel wall can be explained by the presence of rather thick boundary layer on the test section walls. Unfortunately, the boundary layer thickness was not measured in IHM tests. To estimate the corresponding displacement thickness of the laminar boundary layer on the wind tunnel wall, the Blasius solution for the flat plate can be used [21]:

$$
\bar{\delta}^{*}=1.721 \sqrt{\frac{v \bar{x}}{U_{\infty}}}=1.721 L \sqrt{\frac{\bar{x}}{L \operatorname{Re}_{L}}} .
$$

The results of calculations are shown in Table 2 for the cross sections corresponding to the points $2-4$. The values of $\bar{x} / L=4.755 ; 5.255$, and 5.755 corresponding to the distance of the cross sections from the edge of the confusor were taken for calculations. The real values of the boundary layer thickness have to be larger than ones shown in Table 2, since the estimation (4) and the taken values of $\bar{x} / L$ imply a zero value of $\bar{\delta}^{*}$ at the beginning of the tunnel test section. According to Table 2, the area of the boundary layer in the tunnel section is of $2.1-3.8 \%$ of the total cross section area $0.1 \mathrm{~m}^{2}$. The area of the middle model section is $2.5 \%$. It means that the sum of these values can exceed $5 \%$. Thus the flow characteristics in the wind tunnel can differ from the theoretical ones, calculated in the unrestricted inviscid flow.

Table 2. Estimations of the laminar boundary layer thickness (in $\mathrm{mm}$ ) on the walls of the IHM wind tunnel at different performance velocities (Reynolds numbers) without the model

\begin{tabular}{|c|c|c|c|}
\hline$U_{\infty}, \mathrm{m} / \mathrm{s}$ & $\bar{\delta}_{2}^{*}$ & $\bar{\delta}_{3}^{*}$ & $\bar{\delta}_{4}^{*}$ \\
\hline 5.7 & 2.50 & 2.63 & 2.75 \\
\hline 10 & 1.94 & 2.04 & 2.13 \\
\hline 15 & 1.53 & 1.61 & 1.69 \\
\hline
\end{tabular}

The area of the cross section of the ISM wind tunnel is 16.9 greater and the effects of restricted flow can be neglected. That is why, the pressure measurements are much closer to the theoretical values. The existing discrepancies (especially 
upstream to the maximum thickness point $x / L \leq 0.35$, where the good coincidence with the theory must be even in the case of separation) can be explained by the fact that the flow velocity $U_{\infty}$ was measured far upstream from the model location. We used Prandtl probe for this purpose. The orifice for $p_{\infty}$ was also located on the same probe.

The measured $C_{p}^{(m)}$ and real $C_{p}^{(r)}$ values of pressure coefficient are connected by simple relationship:

$$
\begin{gathered}
C_{p}^{(r)}=\frac{2\left(p-p_{\infty}^{(r)}\right)}{\rho\left(U_{\infty}^{2}\right)^{(r)}} \\
\frac{2\left(p-p_{\infty}^{(m)}+p_{\infty}^{(m)}-p_{\infty}^{(r)}\right)}{\beta \rho\left(U_{\infty}^{2}\right)^{(m)}}=\frac{C_{p}^{(m)}}{\beta}+\gamma
\end{gathered}
$$

where coefficient $\beta$ corresponds to the correction of the velocity, $\gamma$ is the correction of the $p_{\infty}$ value (due to the location of the Prandtl probe). Assuming the real values of pressure coefficient $C_{p}^{(r)}$ to be equal to the theoretical values in the region $x / L \leq 0.35$, the unknown values $\beta$ and $\gamma$ can be calculated with the use of (5) and two points with known values of $C_{p}^{(m)}$.

To correct the pressure measurements all the 15 possible couples of 6 orifices located at $x / L \leq 0.35$ were used to calculate the average values of $\beta$ and $\gamma$. The results are shown in Fig. 5 by red markers. It can be seen that corrected values of $C_{p}$ are close to the theoretical curve. This fact shows that there is probably no separation occurred at all the velocity ranges.

The examples of the flow visualization are shown in Figs. 6-8. To make the flow pattern more visible we deposited different oil layers on the model surface. After the wind tunnel flow stabilization the thick layer yields more or less regular zone of oil concentration (see Fig. 6, A). In these zones the oil doesn't move along the flow. Some vertical movements due to the gravity are visible (see Fig. 6, A). The length of these zones diminishes with the increase of the Reynolds number (their leading and trailing edges are shown in Fig. 9 by vertical lines). The thickness of these layers (normal to the wall) was not measured, but its diminishing over time was visible (the oil was removed by shear stresses and evaporation). Evidently, these processes were faster at higher velocities. Finally, in the oil concentration zones, some irregular structures occur (see Fig. 8). A thin layer of the deposited oil yields two irregular zones of the oil concentration, located near the points $x=0.46$ and $x=0.56$ (see Fig. 7). The differences in the oil flow patterns between these sections and downstream are not considerable.

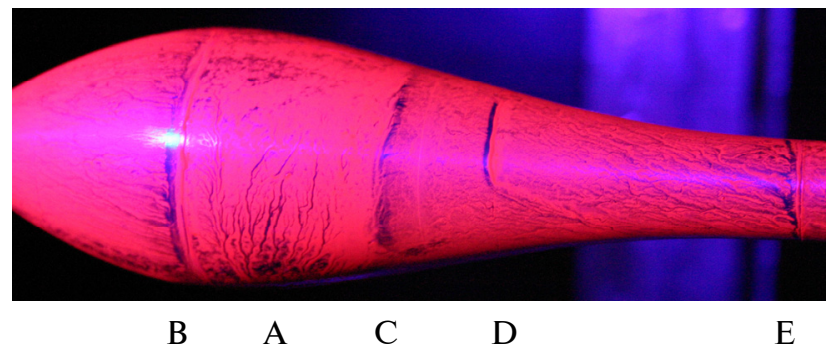

Fig. 6. The oil-flow visualization at the velocity $15 \mathrm{~m} / \mathrm{s}\left(\operatorname{Re}_{L}=\right.$ $\left.=1.9 \times 10^{5}\right) ; \mathrm{A}-\mathrm{A}$ large oil concentration zone; $\mathrm{B}, \mathrm{C}$, $\mathrm{D}$, and $\mathrm{E}-$ small zones of probable flow separation

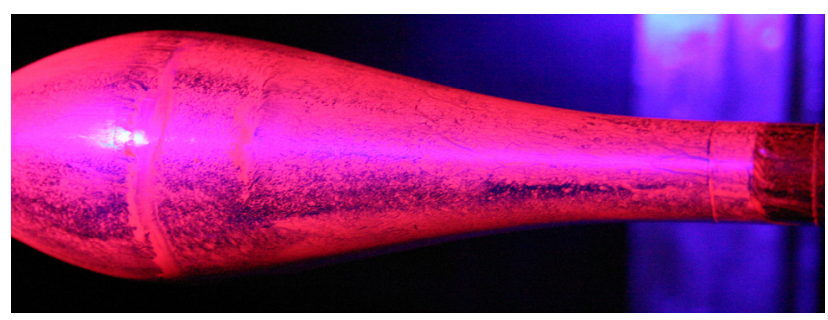

A

B

Fig. 7. The oil-flow visualization at the velocity $35 \mathrm{~m} / \mathrm{s}\left(\operatorname{Re}_{L}=\right.$ $\left.=4.5 \times 10^{5}\right) ; \mathrm{A}$ and $\mathrm{B}-$ two small oil concentration zones

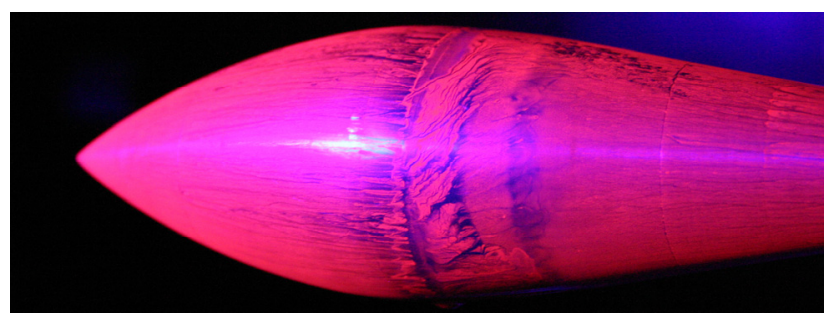

A

Fig. 8. The flow visualization at the velocity $55 \mathrm{~m} / \mathrm{s}\left(\operatorname{Re}_{L}=\right.$ $\left.=6.9 \times 10^{5}\right) ; \mathrm{A}-$ irregular structures in the oil concentration zone

The oil concentration zones are located at the areas of the real pressure increase (blue markers in Fig. 9). In a typical separation bubble the pressure changes are insignificant. In Fig. 9 we can see such zone only in vicinity of the point $x=0.55$. If the oil film is in equilibrium at the positive pressure gradient zone, the shear stresses in oil on the airoil boundary has to be directed downstream. It means that the air flow above the oil film is directed along the $x$ axis (there is no reverse flow typical for separation). 


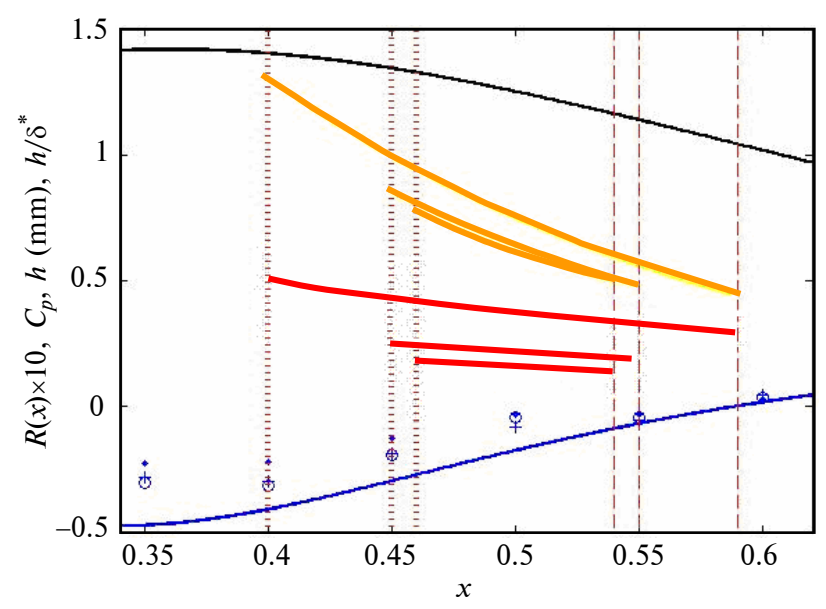

Fig. 9. The oil accumulation zones at different Reynolds numbers (vertical lines. Body radius (black line), theoretical and experimental pressure distributions (blue line and markers). Estimations of the oil layer thickness $h$ in $\mathrm{mm}$ (eq. (8), red lines) and $h / \delta^{*}$ (eq. (10), orange lines), corresponding $\operatorname{Re}_{L}=1.9 \times 10^{5} ; 4.5 \times 10^{5} ; 6.9 \times 10^{5}$ change top to bottom

The equilibrium thickness of the oil layer $h$ can be estimated from the force balance for a short oil ring located on the body surface between sections $x$ and $x+\Delta x$. Then, the positive pressure gradient causes the force $2 \pi R(x) h[p(x)-p(x+\Delta x)]$ $\approx-2 \pi R(x) h \Delta x(d p / d x)$ (the surface slope and curvature are neglected). For the positive pressure gradient zone this force is directed upstream and can be compensated only with the shear stress of the air flow $\tau_{W}$, which must be directed downstream. The corresponding force can be estimated as follows: $2 \pi R(x) \tau_{W} \Delta x$ and the equilibrium thickness of the oil layer is:

$$
h=\tau_{W}\left(\frac{d C_{p}}{d x}\right)^{-1} .
$$

All the lengths in the dimensionless formula (6) are based on the model length, $\tau_{W}$ and the pressure coefficient - on the $0.5 \rho U^{2}$ ( $\rho$ is the density of the air).

For the laminar flow, $\tau_{W}$ can be estimated from the Blasius solution for the plane plate $\bar{\tau}_{W}=$ $=0.664(\bar{x})^{-1 / 2} \operatorname{Re}_{L}^{-1 / 2}$ and the Mangler-Stepanov transformations (see [5, 21]):

$$
\tau_{w}=\bar{\tau}_{w} R(x) ; \delta^{*}=\frac{\bar{\delta}^{*}}{R(x)} ; \bar{x}=\int_{0}^{x} R^{2}(\xi) d \xi .
$$

Then it follows form (6) and (7) that

$$
h=\frac{0.664 R(x)}{\frac{d C_{p}}{d x} \sqrt{\operatorname{Re}_{L} \int_{0}^{x} R^{2}(\xi) d \xi}}
$$

Using (8), the solutions (2), (3) and average values of $d C_{p} / d x$ (calculated with the use of experimental values $C_{p}$ located between the corresponding vertical lines in Fig. 9) the thickness of the oil layers was calculated (see red lines in Fig. 9).

To compare the equilibrium thickness of the oil layer $h$ with the displacement thickness of the boundary layer on the model $\delta^{*}$, the Blasius solution for the plane plate (see (4) [21]) and the Mangler-Stepanov transformations (see (7) [21]) can be used and the following formula can be obtained [5]:

$$
\delta^{*}=\frac{1.721}{R(x) \sqrt{\mathrm{Re}_{L}}} \sqrt{\int_{0}^{x} R^{2}(\xi) d \xi}
$$

which is valid for the slender bodies of revolution $(D / L<<1)$ and when $\delta^{*}(x) / R(x)<<1$. Finally, with the use of (3) and (6) the ratio $h / \delta^{*}$ can be written as follows:

$$
\frac{h}{\delta^{*}}=\frac{0.386 R^{2}(x)}{\frac{d C_{p}}{d x} \int_{0}^{x} R^{2}(\xi) d \xi} .
$$

The results of calculations (see Fig. 9, orange lines*) show that the thickness of the oil film is comparable and even exceeds the boundary layer thickness, especially at smaller Reynolds numbers (the upper line). This fact can cause the changes in the flow pattern, trip the flow and can even lead to the local separation. The blue areas just upstream and downstream to the oil accumulation zone (visible in Fig. 6, B, C, D, E) are the examples of such separation.

Tests results at the angles of attack $-5^{\circ}$ and $-10^{\circ}$. The results of pressure measurements with the down location of the static pressure orifices at different velocity ranges are shown in Figs. 10-12. Even at the maximum angle of attack, the pressure distribution is rather close to one at zero angle of attack and the negative pressure gradient zone still occurs near the tail.

\footnotetext{
* The colour figure see at: http://bulletin.kpi.ua/article/view/129140
} 


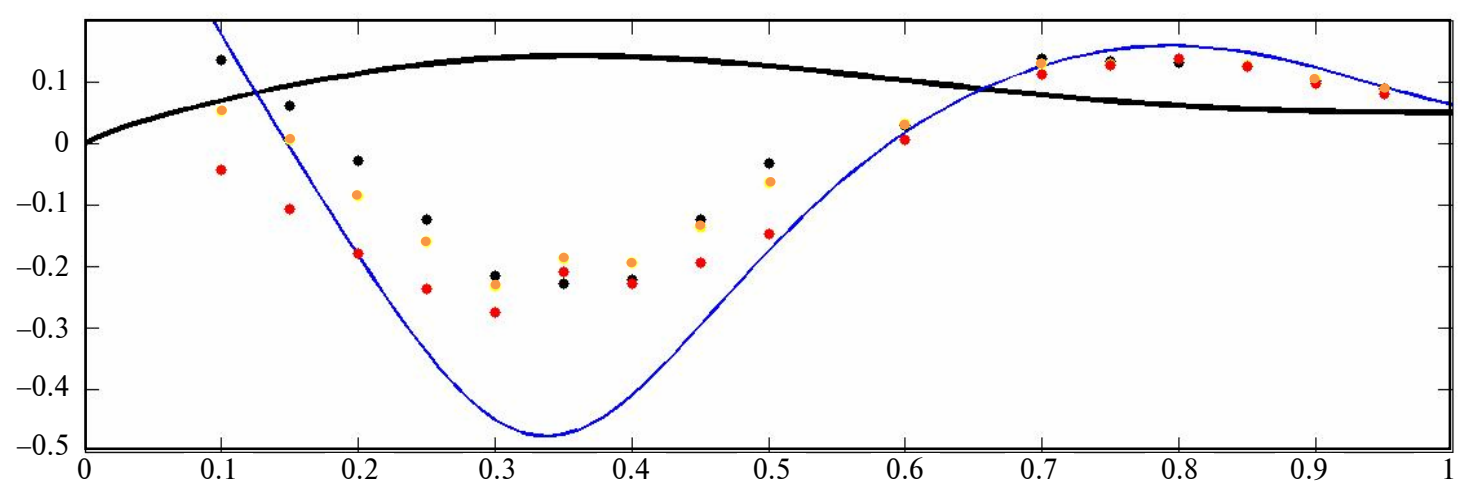

Fig. 10. Experimental pressure distributions for different angles of attack at the velocity $15 \mathrm{~m} / \mathrm{s}\left(\operatorname{Re}_{L}=1.9 \times 10^{5}\right)$. Black markers correspond to the zero angle of attack, orange and red for the $-5^{\circ}$ and $-10^{\circ}$ respectively

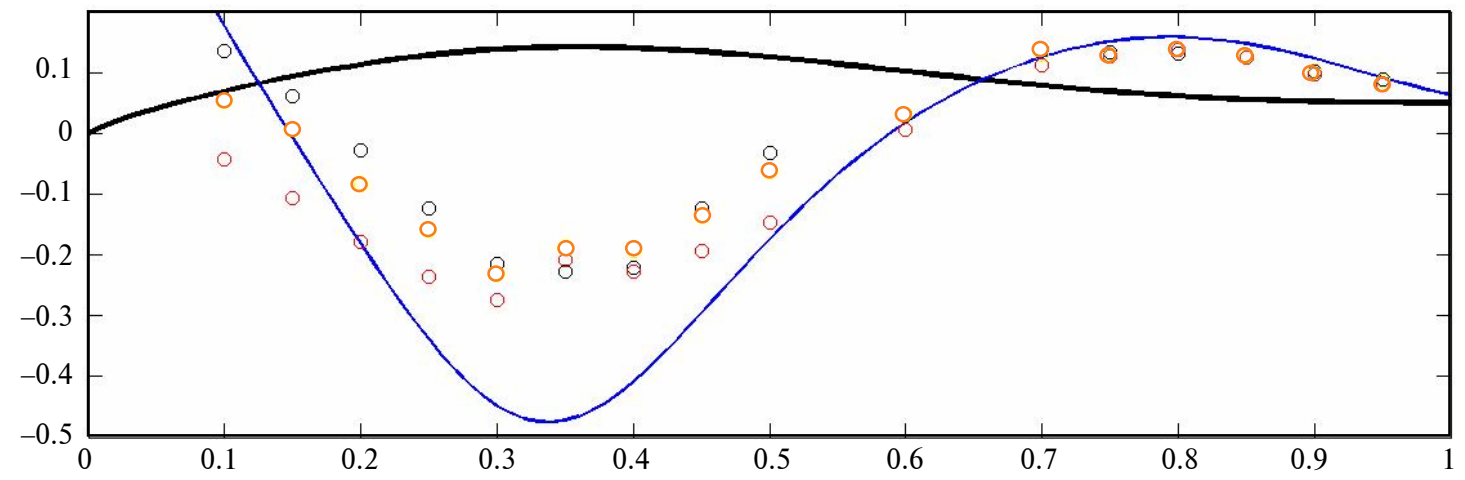

Fig. 11. Experimental pressure distributions for different angles of attack at the velocity $35 \mathrm{~m} / \mathrm{s}\left(\operatorname{Re}_{L}=4.5 \times 10^{5}\right)$. Black markers correspond to the zero angle of attack, orange and red for the $-5^{\circ}$ and $-10^{\circ}$ respectively

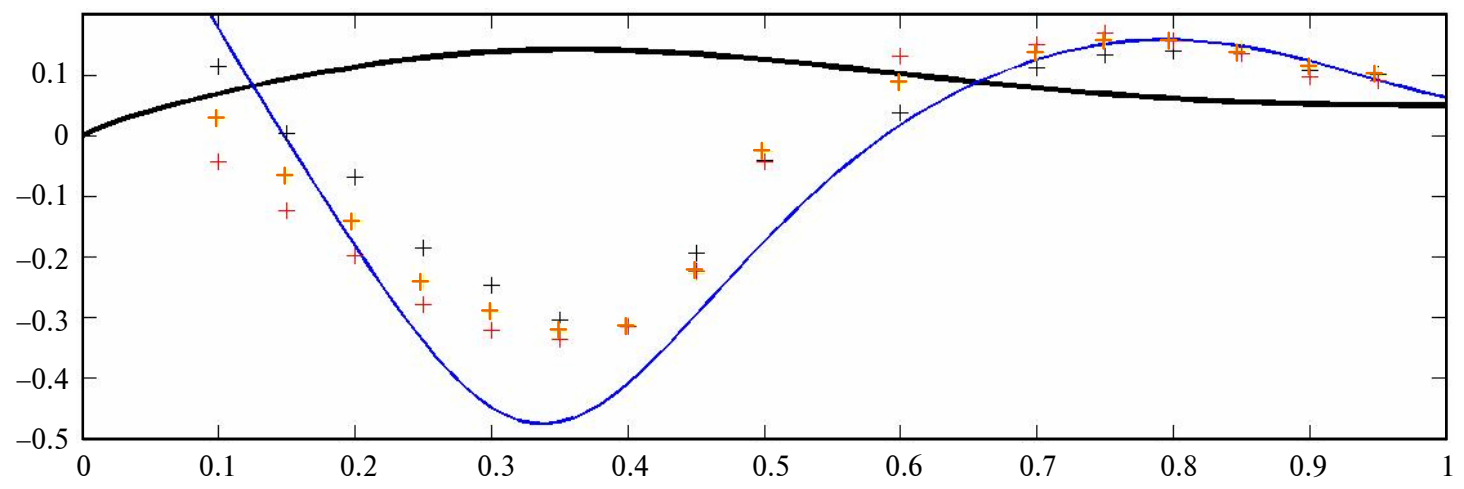

Fig. 12. Experimental pressure distributions for different angles of attack at the velocity $55 \mathrm{~m} / \mathrm{s}\left(\operatorname{Re}_{L}=6.9 \times 10^{5}\right)$. Black markers correspond to the zero angle of attack, orange and red for the $-5^{\circ}$ and $-10^{\circ}$ respectively

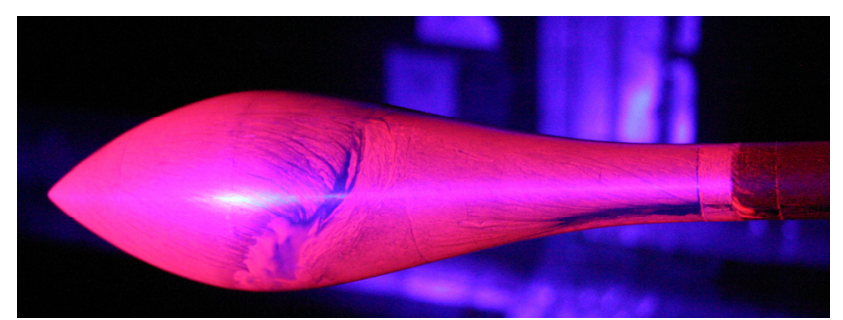

Fig. 13. The flow visualization at the velocity $15 \mathrm{~m} / \mathrm{s}\left(\operatorname{Re}_{L}=\right.$ $=1.9 \times 10^{5}$ ) and the angle of attack $-10^{\circ}$

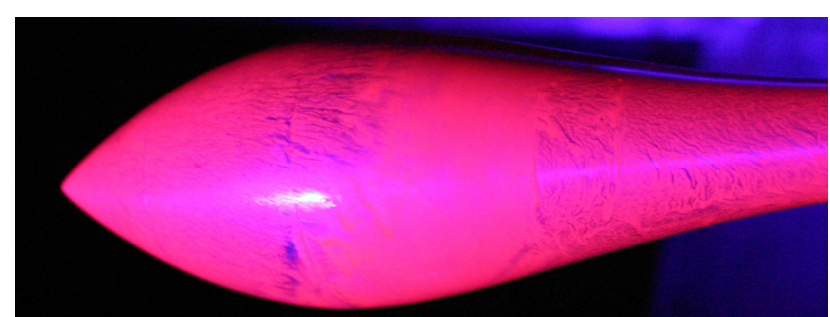

Fig. 14. The flow visualization at the velocity $55 \mathrm{~m} / \mathrm{s}\left(\operatorname{Re}_{L}=\right.$ $=6.9 \times 10^{5}$ ) and the angle of attack $-10^{\circ}$ 
The examples of the flow visualization are shown in Figs. 13 and 14. Asymmetric zones of the oil accumulation are visible at all values of Reynolds number and the angle of attack. The size of these zones diminishes with the increase of the Reynolds number.

\section{Conclusions}

Pressure measurements and the flow visualization on the special shaped body of revolution showed that it is probably possible to avoid separation in rather large range of the Reynolds numbers. Further experiments are necessary with the visualization of the flow volume and hot-wire velocity probes to clarify the behavior of the boundary layer, its separation and laminar-to-turbulent transition characteristics.

\section{Acknowledgements}

The authors thank Prof. Rolf Radespiel and Ralf Wokoeck (TU Braunschweig); Prof. Alberto Redaelli, Prof. Giuseppe Passoni and Prof. Gianfranco Fiore (Politecnico di Milano) and Dr. Volodymyr Moroz (Institute of Hydromechanics, Kyiv) for their support and interesting discussion of the results. The study was supported by EU-financed Horizon-2020 project AMMODIT (Grant Number MSCA-RISE 645672).

\section{References}

[1] J. Gray, "Studies in animal locomotion VI. The propulsive powers of the dolphin", J. Exp.Biol., vol. 13, pp. 192-199, 1936.

[2] Yu.G. Aleyev, Nekton. Springer Netherlands, 1977. doi: 10.1007/978-94-010-1324-6

[3] J. Rohr et al., "Experimental approaches towards interpreting dolphin stimulated bioluminescence", J. Exper. Biol., vol. 201, pp. 1447-1460, 1998.

[4] Underwater Missile Propulsion, L. Greiner, Ed. Compass Publications, 1967.

[5] I. Nesteruk, "Reserves of the hydrodynamical drag reduction for axisymmetric bodies", Bulletin of Univ. of Kiev, Ser.: Phys. \& Math., no. 4, pp. 112-118, 2002.

[6] I. Nesteruk et al., "Shape of aquatic animals and their swimming efficiency", J. Marine Biol., vol. 2014, Article ID 470715, 2014. doi: $10.1155 / 2014 / 470715$

[7] R.J. Hansen and J.G. Hoyt, "Laminar-to-turbulent transition on a body of revolution with an extended favorable pressure gradient forebody", J. Fluids Eng., vol. 106, pp. 202-210, 1984. doi:10.1115/1.3243103

[8] J.S. Parsons et al., "Shaping of axisymmetric bodies for minimum drag in incompressible flow", J. Hydronautics, vol. 8, no. 3, pp. $100-107$, 1974. doi: $10.2514 / 3.48131$

[9] S.S. Dodbele et al., "Shaping of airplane fuselages for minimum drag", J. Aircraft, vol. 24, pp. $298-304$, 1987. doi: $10.2514 / 3.45444$

[10] M.F. Zedan et al., "Drag reduction of fuselages through shaping by the inverse method", J. Aircraft, vol. 31, no. 2, pp. 279287, 1994. doi: $10.2514 / 3.46485$

[11] Th. Lutz and S. Wagner, "Drag reduction and shape optimization of airship bodies", J. Aircraft, vol. 35, no. 3, pp. 345-351, 1998. doi: $10.2514 / 2.2313$

[12] I. Nesteruk, "Peculiarities of turbulization and separation of boundary-layer on slender axisymmetric subsonic bodies", Naukovi Visti NTUU KPI, no. 3, pp. 70-76, 2002 (in Ukrainian).

[13] I. Nesteruk, "Rigid bodies without boundary-layer separation”, Int. J. Fluid Mech. Res., vol. 41, no. 3, pp. 260-281, 2014. doi: 10.1615/InterJFluidMechRes.v41.i3.50

[14] I. Nesteruk, "New type of unseparated subsonic shape of axisymmetric body", Reports of the National Academy of Sciences of Ukraine, no. 11, pp. 49-56, 2003 (in Ukrainian).

[15] F.R. Goldschmied, "Integrated hull design, boundary layer control and propulsion of submerged bodies: Wind tunnel verification”, in Proc. AIAA/SAE/ASME 18th Joint Propulsion Conf. (AIAA (82-1204)), pp. 3-18, 1982. doi: 10.2514/6.1982-1204

[16] P. Polivanov et al., "Effects of local wall heating and cooling on hypersonic boundary-layer stability", in Proc. SFBTRR40 Summer Research Program, Munich (2011), 17 p.

[17] J. Becker et al., "The future role of smart structure systems in modern aircraft", J. Smart Structures and Systems, vol. 1, no. 2, pp. 159-185, 2005.

[18] K.-S. Choi et al., "Turbulent boundary-layer control with plasma actuators", Ph. Trans. Royal Soc. A, vol. 369, pp. 14431458, 2011. doi: 10.1098/rsta.2010.0362

[19] J.H.M. Fransson et al., "Delaying transition to turbulence by a passive mechanism", Phys. Rev. Lett., vol. 96, no. 064501, 2006. doi: 10.1103/PhysRevLett.96.064501

[20] I. Nesteruk, "Technology applications of the low drag shapes of aquatic animals", Biosci. Bioeng., vol. 1, no. 2, pp. $29-33,2015$.

[21] L.G. Loitsyanskiy, Mechanics of Liquids and Gases, 6th ed. New York, Wallingford: Begell House, 1995. 
І.Г. Нестерук, М. Брюль, Т. Мьоллер

\section{ДОСЛІДЖЕННЯ ТІЛА ОБЕРТАННЯ СПЕЦІАЛЬНОЇ ФОРМИ, ПОДІБНОЇ ДО ТУЛУБА ДЕЛЬФІНА}

Проблематика. Високі швидкості плавання деяких водних тварин продовжують викликати значний інтерес дослідників. Опір тертя дельфріна, оцінений з використанням турбулентного коефіцієнта тертя на плоскій пластині, виявився занадто високим, щоб стверджувати, що дельфін не здатний рухатися так швидко, як він це робить, з властивою йому мускульною силою. Деякі попередні експерименти з твердими тілами, за формою подібними до тіла тварин, та з дельфінами, що рухались за інерцією, виявили безвідривне обтікання. Однак дослідники, пов'язані з технікою, вважають, що відрив неминучий на будь-якій гладкій формі, якщо не застосовувати активних методів керування примежовим шаром (наприклад, відсмоктування).

Мета дослідження. Показати за допомогою аеродинамічних експериментів, що на твердих тілах обертання спеціальної форми можна уникнути відриву примежового шару без жодних активних методів керування потоком.

Методика реалізації. Експерименти проводились в аеродинамічній трубі на швидкостях 15, 35 і 55 м/с. Використовувались вимірювання статичного тиску та візуалізація за допомогою течії олії. Для цього дослідження було взято модель UA-2 спеціальної форми довжиною 200 мм і максимальним діаметром 56,78 мм. Замкнена версія цієї моделі - UA-2c - $€$ подібною до тіла дельфріна. Дослідження проводились у дозвуковій аеродинамічній трубі MUB Інституту механіки потоків (ISM) Технічного університету Брауншвайга, Німеччина. Труба MUB у ISM є установкою геттінгенського типу з активним охолодженням, квадратним перерізом робочої частини зі стороною 1,3 м і рівнем турбулентності приблизно 0,2 \%. Для отримання інформації про потік біля поверхні використовувалась візуалізація за допомогою течії олії. Застосовувалась фрарба, що є сумішшю мінерального масла та бензину в оптимізованій пропорції. Дуже дрібні частинки діоксину титану та полімерні частинки, що реагують на ультрафріолетове світло, забезпечували висококонтрастне зображення з високою просторовою роздільною здатністю.

Результати дослідження. Наведено розподіли статичного тиску та результати візуалізації за допомогою течії олії для трьох значень кута атаки. При нульовому куті атаки обтікання, ймовірно, $є$ безвідривним і ламінарним.

Висновки. Вимірювання тиску та візуалізація потоку на тілі обертання спеціальної фрорми показали, що, ймовірно, можна уникнути відриву в досить широкому діапазоні чисел Рейнольдса. Потрібні подальші експерименти з використанням візуалізації об'єму потоку та термодатчиків швидкості для уточнення поведінки примежового шару, характеристик його відриву та турбулізації.

Ключові слова: аеродинамічні експерименти; зменшення опору; відрив примежового шару; візуалізація потоку; водні тварини.

\section{И.Г. Нестерук, М. Брюлль, Т. Мёллер}

\section{ИССЛЕДОВАНИЯ ТЕЛА ВРАЩЕНИЯ СПЕЦИАЛЬНОЙ ФОРМЫ, ПОДОБНОЙ ТУЛОВИЩУ ДЕЛЬФИНА}

Проблематика. Высокие скорости плавания некоторых водных животных продолжают вызывать большой интерес исследователей. Оценка сопротивления трения дельфина с использованием турбулентного коэффициента трения на плоской пластине оказалась слишком высокой, чтобы утверждать, что дельфин не способен двигаться так быстро, как он это делает, с присущей ему мускульной силой. Некоторые предыдущие эксперименты с твердыми телами, по форме подобными телам животных, и с движущимися по инерции дельфинами выявили безотрывное обтекание. Однако исследователи, связанные с техникой, считают, что отрыв неизбежен на любой гладкой форме, если не использовать активных методов управления пограничным слоем (например, отсос).

Цель исследования. Показать с помощью аэродинамических экспериментов, что на твердых телах вращения специальной формы можно избежать отрыва пограничного слоя без каких-либо активных методов управления потоком.

Методика реализации. Эксперименты проводились в аэродинамической трубе на скоростях 15, 35 и 55 м/с. Применялись измерение статического давления и визуализация с помощью течения масла. Для этого исследования была взята модель UA-2 специальной формы длиной 200 мм и максимальным диаметром 56,78 мм. Замкнутая версия этой модели - UA-2c - похожа на тело дельфина. Исследования проводились в дозвуковой аэродинамической трубе МUВ Института механики потоков (ISM) Технического университета Брауншвайга, Германия. Труба MUB в ISM представляет собой установку геттингенского типа с активным охлаждением, квадратным сечением рабочей части со стороной 1,3 м и уровнем турбулентности приблизительно $0,2 \%$. Для получения информации о потоке вблизи поверхности применялась визуализация с использованием течения масла. Использовалась краска в виде смеси минерального масла и бензина в оптимизированной пропорции. Очень мелкие частицы диоксида титана и полимерные частицы, реагирующие на ультрафиолетовый свет, обеспечивали высококонтрастное изображение с высокой пространственной разрешающей способностью.

Результаты исследования. Представлены распределения статического давления и результаты визуализации с помощью течения масла для трех значений угла атаки. При нулевом угле атаки течение, вероятно, было безотрывным и ламинарным.

Выводы. Измерения давления и визуализация потока на теле вращения специальной формы показали, что, вероятно, можно избежать отрыва в достаточно широком диапазоне чисел Рейнольдса. Нужны дополнительные эксперименты с использованием визуализации объема потока и термодатчиков для уточнения поведения пограничного слоя, характеристик его отрыва и турбулизации.

Ключевые слова: аэродинамические эксперименты; снижение сопротивления; отрыв пограничного слоя; визуализация потока; водные животные.

Рекомендована Радою

Механіко-машинобудівного інституту

КПІ ім. Ігоря Сікорського
Надійшла до редакції 15 лютого 2018 року

Прийнята до публікації 29 березня 2018 року 
